\title{
The Use of Seismic Attributes to Enhance Structural Interpretation of Z-Field, Onshore Niger Delta
}

\author{
E. A. Ayolabi ${ }^{1} \&$ A. O. Adigun ${ }^{1}$ \\ ${ }^{1}$ Department of Geosciences, Faculty of Science, University of Lagos, Lagos State, Nigeria \\ Correspondence: E. A. Ayolabi, Department of Geoscience, University of Lagos, Lagos, Nigeria. Tel: \\ 234-803-720-6074. E-mail: eojelabi@yahoo.com
}

Received: April 8, 2013 Accepted: July 19, 2013 Online Published: July 29, 2013

doi:10.5539/esr.v2n2p223 URL: http://dx.doi.org/10.5539/esr.v2n2p223

\begin{abstract}
An integrated approach to the study of the structural patterns and seismic attributes was carried out on the Z-field using a 3D seismic data covering approximately $56 \mathrm{Km}^{2}$ of western belt of the Niger Delta, checkshot data for well to seismic tie and log information for six wells from the field. This study aimed at investigating the available prospects, the responses of the basic seismic attributes to structural and stratigraphic elements within the study area. In all, six hydrocarbon bearing levels were delineated from well logs and correlated across the field. These horizons were analysed and petrophysical parameters estimated. An integration of well and seismic data was done by applying a time-depth relationship to identify where the hydrocarbon bearing sands from well posts on the seismic lines. These studies revealed two major regional growth faults (F1 and F5) dipping in the NE-SW directions and crestal faults (F4) dipping in the northern direction. The north dipping crestal fault F4 is responsible for holding the hydrocarbon in the proven closure A. The northernmost regional growth fault F1 is responsible for trapping the hydrocarbon in the prospect closure B in the north eastern part of the field. The closure $\mathrm{C}$ prospect is a four way dip closure to the spill point but becomes fault assisted on regional growth faults F1 and F5 at deeper levels. The trapping mechanism identified from our interpretation indicates that the field is characterized mostly by fault assisted closures and a few four way closures. The fault zones are identified by distinct displacement of walls and amplitude distortions towards the fault zones identified on the seismic sections and the extracted amplitude maps. At the south-western part of the field, using only seismic Stratigraphic approach, a part of fault F5 was too subtle to be identified, and this may lead to missing out on the potentials of the identified closure C prospect. Thus, where conventional seismic interpretation has failed, seismic attribute analysis complements.
\end{abstract}

Keywords: integrated, attributes, faults, closure, amplitude

\section{Introduction}

Conventional seismic stratigraphic interpretation of data has been the popular way of interpreting seismic data for the purpose of mapping geological structures, subsurface stratigraphy and reservoir architecture. The geometrical expression of seismic reflectors is qualitatively mapped in time with little or no emphasis on the inherent seismic amplitude variations (Avseth et al., 2005). However, the introduction of the 3D seismic revolution has made the use of amplitudes an integral part of seismic interpretation and has allowed more valuable geological information to be discerned as seismic attributes (i.e. phase, amplitude, instantaneous frequency etc.)

Seismic attributes form an integral part of qualitative interpretative tool that facilitates structural and stratigraphic (channels, pinch out, meanders, etc) interpretation as well as offer clues to lithology type and fluid content estimation with a potential benefit of detailed reservoir characterization (Strecker et al., 2004). For instance, fault structures which have been classified into seismically resolvable and sub-seismic scale (subtle) faults (Gauthier \& Lake, 1993) can be interpreted more effectively with the aid of seismic attribute. Though the seismically resolvable faults may be interpreted using traditional diagnostic criteria (e.g. abrupt reflector cut off, kinks etc), but the subtle faults which are often of geological or exploration significance are usually not visibly imaged by the conventional seismic sections and time slices displays. This is because they have smaller throws relative to the resolution limit of the seismic survey, which is a factor dependent on the frequency content, signal 
to noise ratio (SNR) of the dataset and also the depth to the reflecting horizon. The subtle fault identified in the southwestern part of the field along fault F5 motivated this study.

In this paper, we have subjected interpreted horizons in time converted to depth (using conventional structural seismic interpretation technique) to seismic attribute generation and analysis. Seismic attribute analysis helps to identify structural features missed using the conventional method of interpretation. It is important to note that not only does seismic attribute analysis help to identify structural features, it also helps to increase the chances of success and development of new prospect areas in the study area. The datasets were loaded into the interpretative tools, in this case, Landmarks Geographix and Schlumberger Petrel.

\section{Theoretical Background}

Seismic attributes are defined as all the information obtained from seismic data, either by direct measurements or by logical or experience based reasoning (Taner, 2001). Seismic attributes are essentially derivatives of the basic seismic measurements i.e. time, amplitude, frequency and attenuation which also form the basis of their classification (Brown, 2004). It was also defined by Sheriff, 1992; as a measurement based on seismic data such as envelope, instantaneous phase, instantaneous frequency, polarity, dip and dip azimuth, etc. It is important to note that attribute interpretation supplements conventional structural interpretation and the discriminating properties of the attributes set may be critically checked for its relevance for a particular problem of a prospect.

The seismic data is treated as an analytic trace which contains real components (original input trace) and the complex (imaginary) component, usually generated from the Hilbert transforms from which various amplitudes, phase and frequency attributes can be deduced (Nissen, 2002). This complex trace allows the amplitude, phase, frequency and reflector polarity attributes of a seismic data to be calculated in a rigorous mathematical sense (Stuart, 2005).

Assuming a seismic trace of the form:

$$
g(t)=A(t) \cos 2 \pi v t
$$

$A(t)$ is the envelope of $g(t)$ and varies slowly with respect to $\cos 2 \pi v t$.

For constant $\mathrm{A}(\mathrm{t})$, the Hilbert transform of $\mathrm{g}(\mathrm{t})$ is given by:

$$
g(t) \Leftrightarrow g \perp(t)=-A(t) \sin 2 \pi v t
$$

Thus we can form a complex signal $h(t)$ where:

$$
h(t)=g(t)+j g \perp(t)=A(t) e^{-j 2 \pi v t}
$$

$\mathrm{h}(\mathrm{t})$ is known as the analytical or complex trace (Bracewell, 1965).

$\mathrm{g} \perp(\mathrm{t})$ is the quadrature trace of $\mathrm{g}(\mathrm{t})$ (Figure 1). If $\mathrm{v}$ is not constant but varies slowly, we define the instantaneous frequency $v(t)$ as the time derivative of the instantaneous phase $\gamma(t)$ thus:

$$
2 \pi v i(t)=\frac{d \gamma(t)}{d t}=\frac{d(2 \pi v t)}{d t}
$$

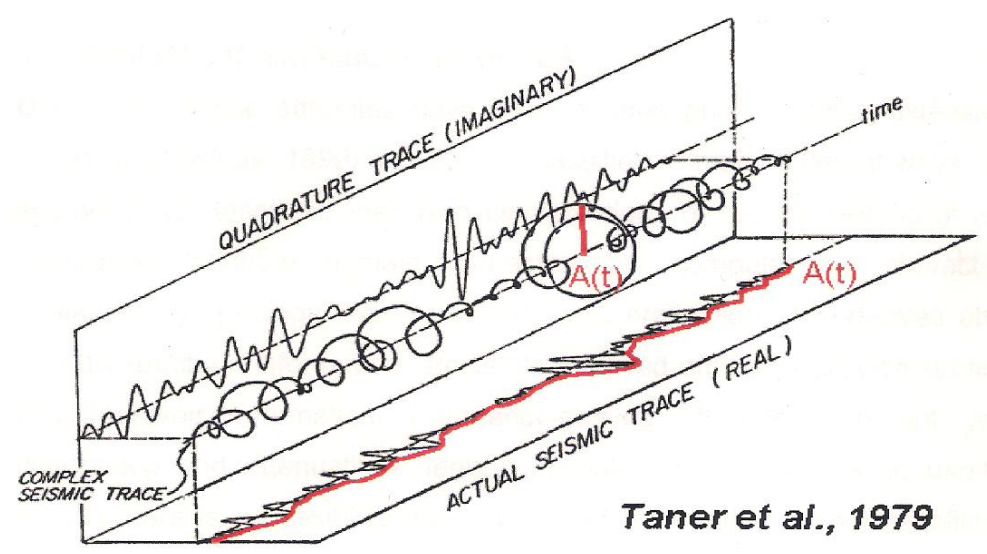

Figure 1. The complex trace shown as a helix of variable amplitude in the direction of time axis. It consists of the real component (original seismic trace); and the imaginary (quadrature) component 
The quantities $\mathrm{A}(\mathrm{t}), \gamma(\mathrm{t})$ and $\mathrm{v}(\mathrm{t})$ and other measurements derivable from the seismic data are referred to as attributes (Sheriff \& Geldart, 1995).

A simpler mathematical description of the complex trace $\mathrm{g}(\mathrm{t})$ of a seismic trace is stated thus:

$$
g(t)=X(t)+i Y(t)
$$

Hence the amplitude $a(t)$ is given by:

$$
a(t)=\left[X^{2}(t)+Y^{2}(t)\right]^{1 / 2}
$$

The phase $\Phi(\mathrm{t})$ is given by:

$$
\Phi(t)=\tan ^{-1}[Y(t) / \quad X(t)]
$$

While the instantaneous frequency (f) is the time derivative of the instantaneous phase thus:

$$
f=\frac{d(\Phi(t))}{d t}
$$

\section{Location and Geology of Study Area}

The study area is within the Niger Delta Basin in southern Nigeria. The Niger Delta is one of the most prolific hydrocarbon provinces in the world. It has a regressive clastic succession of about 10-12km thick, comprising a shelf, broad slope area and basin floor (Morgan, 2004). The Delta lies on a thick prism of clastic sediments which forms the prominent seaward bulge in the continental margin off southern Nigeria (Damuth, 1994). The Niger Delta is an active Paleocene to Recent, wave dominated delta situated on the Atlantic coast of West Africa. Sedimentation in the Niger Delta began following the Albian rift fill deposits (Doust, 1989), between latitudes $3^{\circ}$ and $6^{\circ} \mathrm{N}$ and longitudes $5^{\circ}$ and $8^{\circ} \mathrm{E}$ and extends throughout the Niger Delta Province as defined by Klett et al. (1997).

Generally, sediment inflow is North-South as the clastic sediments are sourced from the high mountains from the north into rivers Niger and Benue. These two rivers merge at a confluence and continue the sediment transportation to form the Delta as it enters into the Atlantic Ocean. The Niger Delta Province contains only one identified petroleum system (Kulke, 1995; Ekweozor \& Daukoru, 1994). This system is referred to here as the Tertiary Niger Delta (Akata - Agbada) Petroleum System. The base of the sequence, consist of massive and monotonous marine shales (Akata Shales) except at the deepwater of the north western area where it has been found to overlie and onlap an older progradational package (Morgan, 2004). This grades upward into interbedded shallow marine and fluvial sand, silts, and clays, which form the typical paralic facies portion of the delta (Agbada Formation). The uppermost part of the sequence is a massive non-marine sand section (Benin Formation). The total thickness of this composite sequence is not precisely known, but may reach $12 \mathrm{~km}$ in the basin center with an estimated area of about $75000 \mathrm{~km}^{2}$ as defined officially by the Nigerian government. Gravity and magnetic data suggest that the maximum thickness lies in the area between Warri and Port Harcourt. The oldest continental sand in the Benin Formation is Oligocene. The Agbada Formation ranges in age from Eocene to Pleistocene and forms the hydrocarbon prospective sequence in the Niger Delta. The Akata Formation ranges in age from Paleocene to Holocene (Doust \& Omatsola, 1990).

However, studies from a producing deepwater field have ascribed upper Oligocene age to the lowermost part of the Agbada unit and inferred the Akata interval to be pre-Miocene in the lower delta slope (Chapin et al., 2002). 


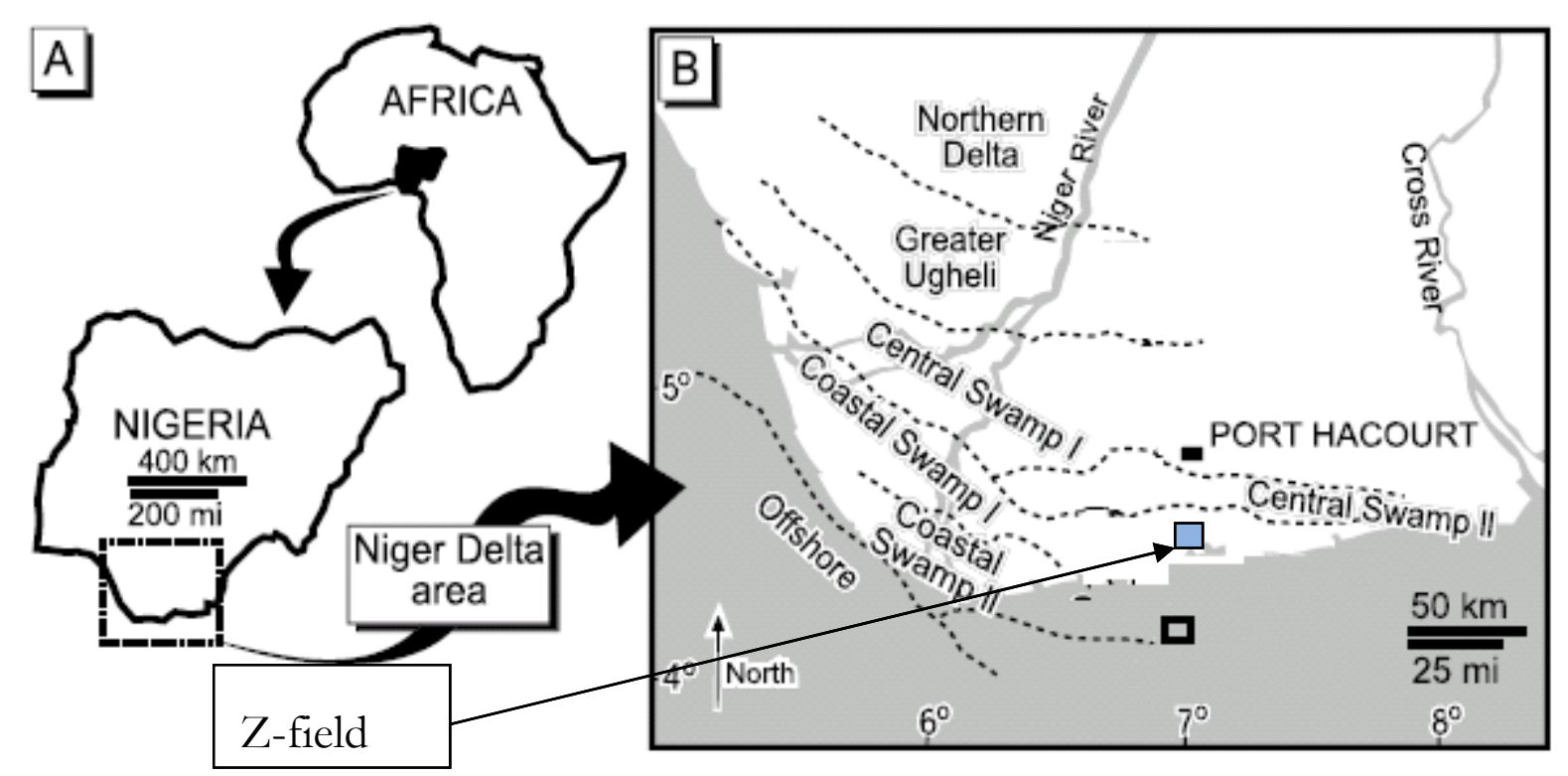

Figure 2. Location of the study area

The study area is located in the onshore region of the Niger Delta (Figure 2). It covers about $56 \mathrm{~km}^{2}$ of the coastal swamp belt onshore eastern Niger Delta. The oil mining license was obtained in June 1967, development and production of Oil commenced immediately. The real name of the field is not given for proprietary sake but named Z-field for the purpose of this study.

\section{Results and Discussion}

The selected reservoirs for the study are located at about $9500 \mathrm{ft}$ to $11500 \mathrm{ft}$ ( $2400 \mathrm{~ms}$ to $2800 \mathrm{~ms})$ in the coastal swamp belt, onshore Niger Delta. The study area is generally characterized by growth faults, some of which are sub-seismic. Conventional seismic interpretation cannot resolve sub-seismic faults, attribute extraction and analysis can. The attributes used in this study to resolve sub-seismic faults is applicable to every other field.

\subsection{Petrophysical Evaluation}

Wireline logs for six wells were used to delineate six hydrocarbon bearing reservoirs in the field (Figure 3). Table 1 below shows the summary of the petrophysical evaluation carried out on three of the reservoirs penetrated by the six wells.

Table 1. Average values for parameters in reservoirs D, E and F

\begin{tabular}{lllllll}
\hline Reservoirs & Net pay & N/G pay & N/G res & Phi pay & Sw & Vshl \\
\hline D & 16 & 0.03 & 0.90 & 0.230 & 0.44 & 0.27 \\
E & 34 & 0.32 & 0.80 & 0.20 & 0.37 & 0.16 \\
F & 75 & 0.60 & 0.81 & 0.22 & 0.24 & 0.20 \\
\hline
\end{tabular}

The identification of reservoirs shows that only Well Z1 encountered hydrocarbon in the six reservoir levels. Only three reservoirs were penetrated by more than one well as summarized in Table 2. 


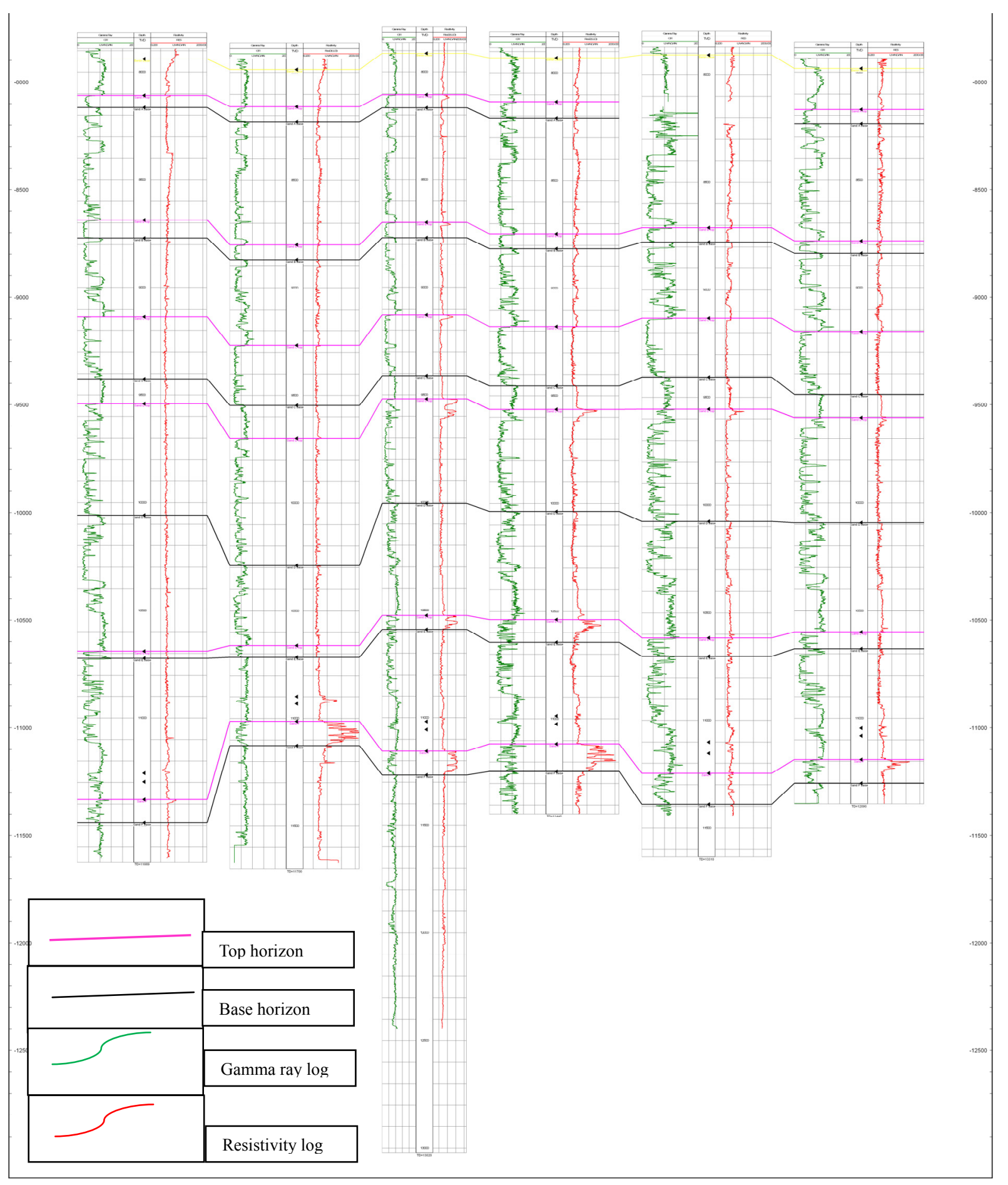

Figure 3. Structural correlation of wells in the NW-SE direction in Z2, Z5, Z1, Z4, Z6, and Z3 order 
Table 2. Showing horizons in different wells with their corresponding fluid content

\begin{tabular}{lllllll}
\hline Horizons & Z1 & Z2 & Z3 & Z4 & Z5 & Z6 \\
\hline A & HC & wet & wet & wet & wet & missing \\
B & HC & wet & wet & wet & wet & wet \\
C & HC & wet & wet & wet & wet & wet \\
D & HC & wet & HC & HC & wet & HC \\
E & HC & wet & wet & HC & missing & wet \\
F & HC & HC & HC & HC & HC & wet \\
\hline
\end{tabular}

The provided checkshot for well Z1 was used to tie well picks to seismic. The plot of time against depth from the checkshot is shown in Figure 4.

Linear equation relating depth to time; $y=m x+c$,

$$
\mathrm{Y}=4.5817 \mathrm{x}-1165.2
$$

Where $\mathrm{Y}=$ depth information from well data

$\mathrm{X}=$ time information from checkshot

$\mathrm{M}=$ slope of plot

$\mathrm{C}=$ intercept

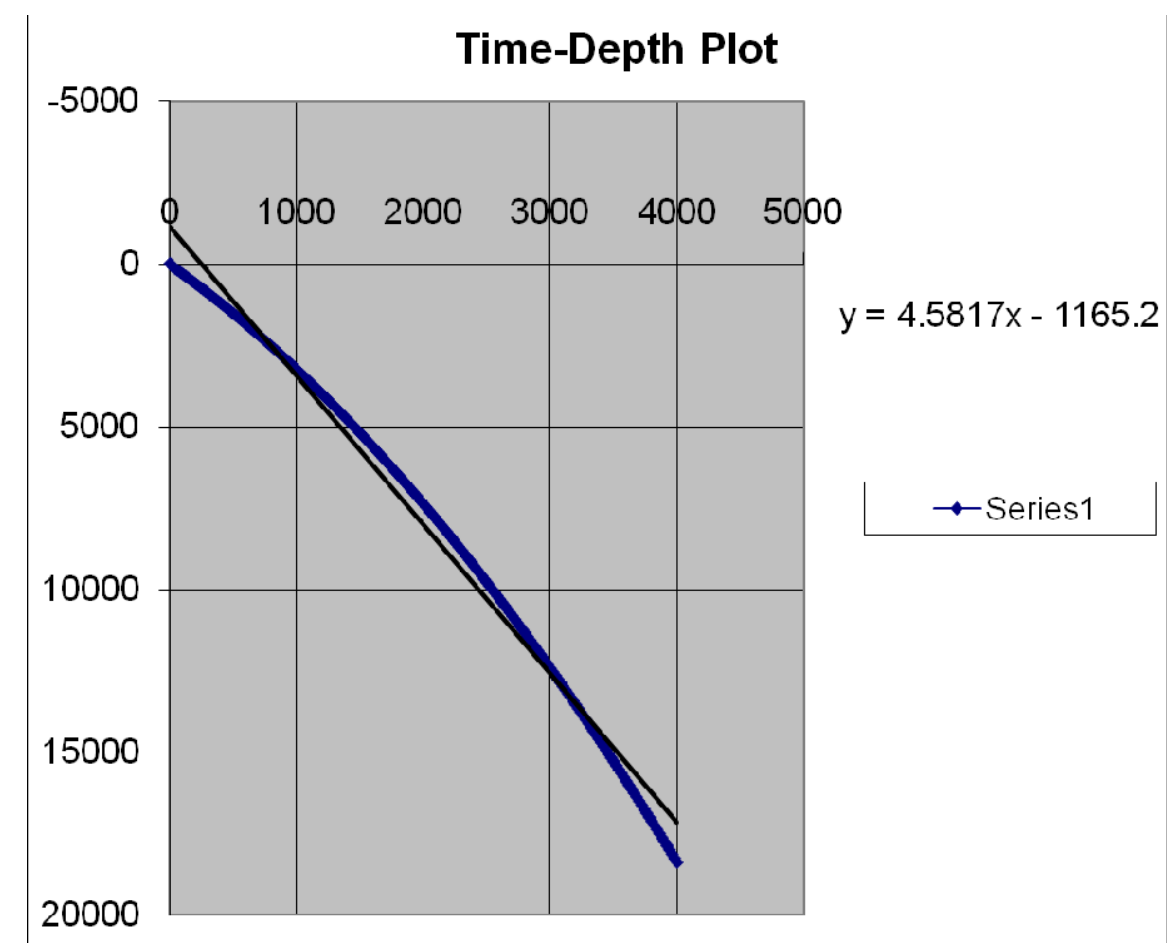

Figure 4. Time-Depth plot of the checkshot 


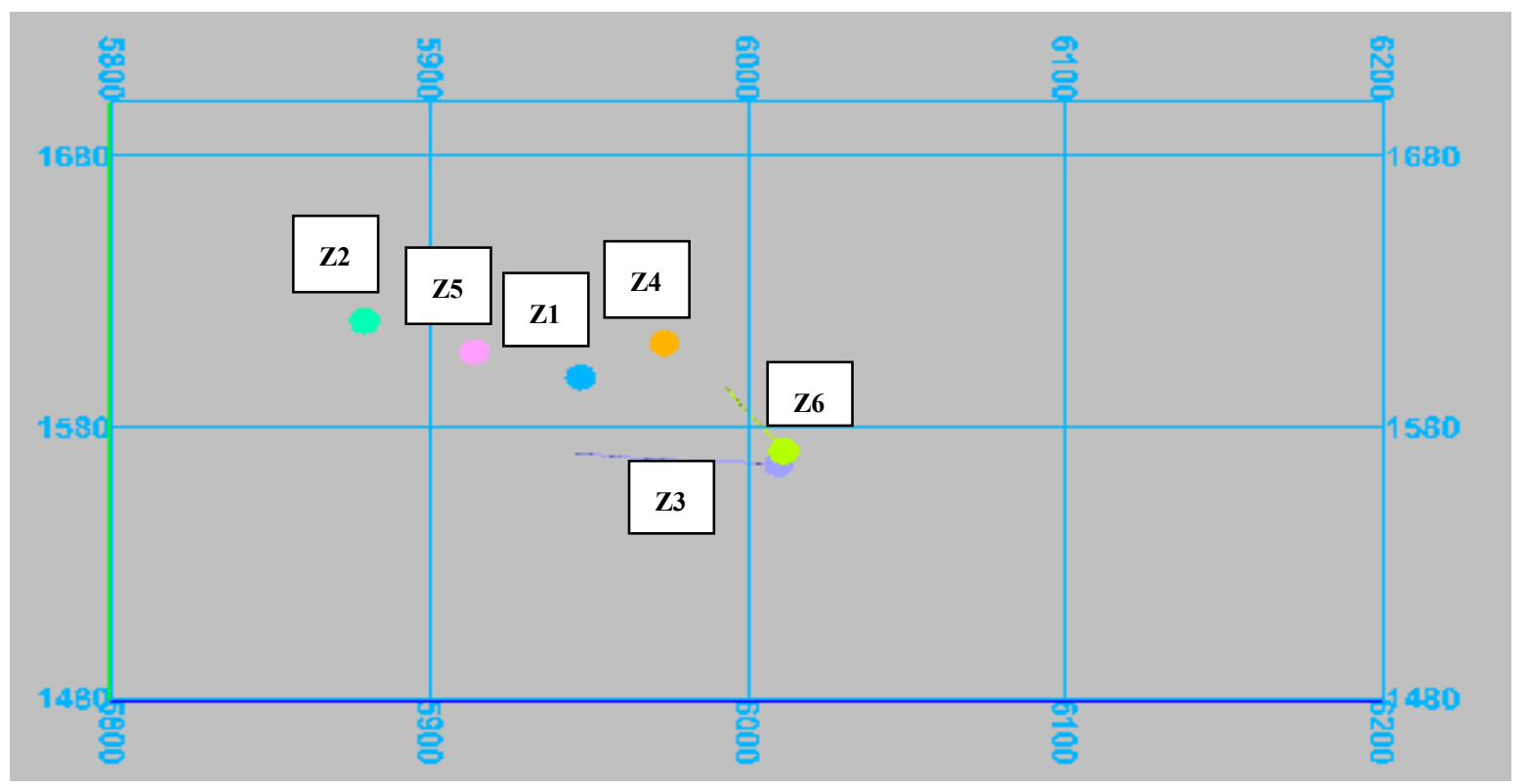

Figure 5. Base map of the study area showing well locations of Z2, Z5, Z1, Z4, Z6 and Z3 respectively

\subsection{Seismic Interpretation}

Seismic to well tie was done by using the checkshot provided for Well Z1. Table 3, Figures $6 \mathrm{~b}$ and 7 below shows the horizons and corresponding time events on seismic.

Table 3. Horizons with their corresponding event on seismic

\begin{tabular}{lll}
\hline Horizon & Corresponding event & Time $(\mathrm{ms})$ \\
\hline 1 & Peak & 2155 \\
2 & Trough & 2277 \\
3 & Peak & 2368 \\
4 & Peak & 2446 \\
5 & Trough & 2644 \\
6 & Trough & 2764 \\
\hline
\end{tabular}




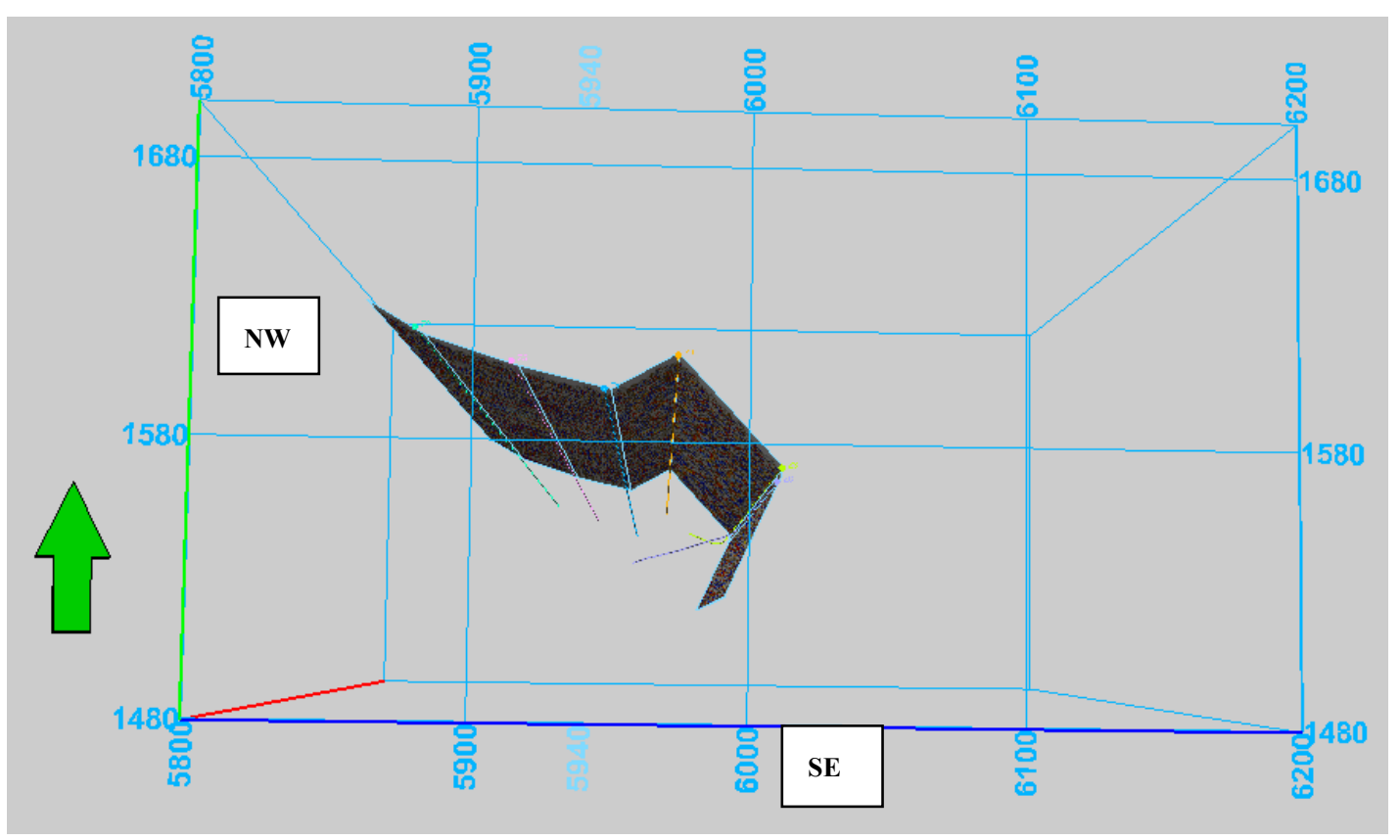

Figure 6a. An arbitrary line along wells direction and positions

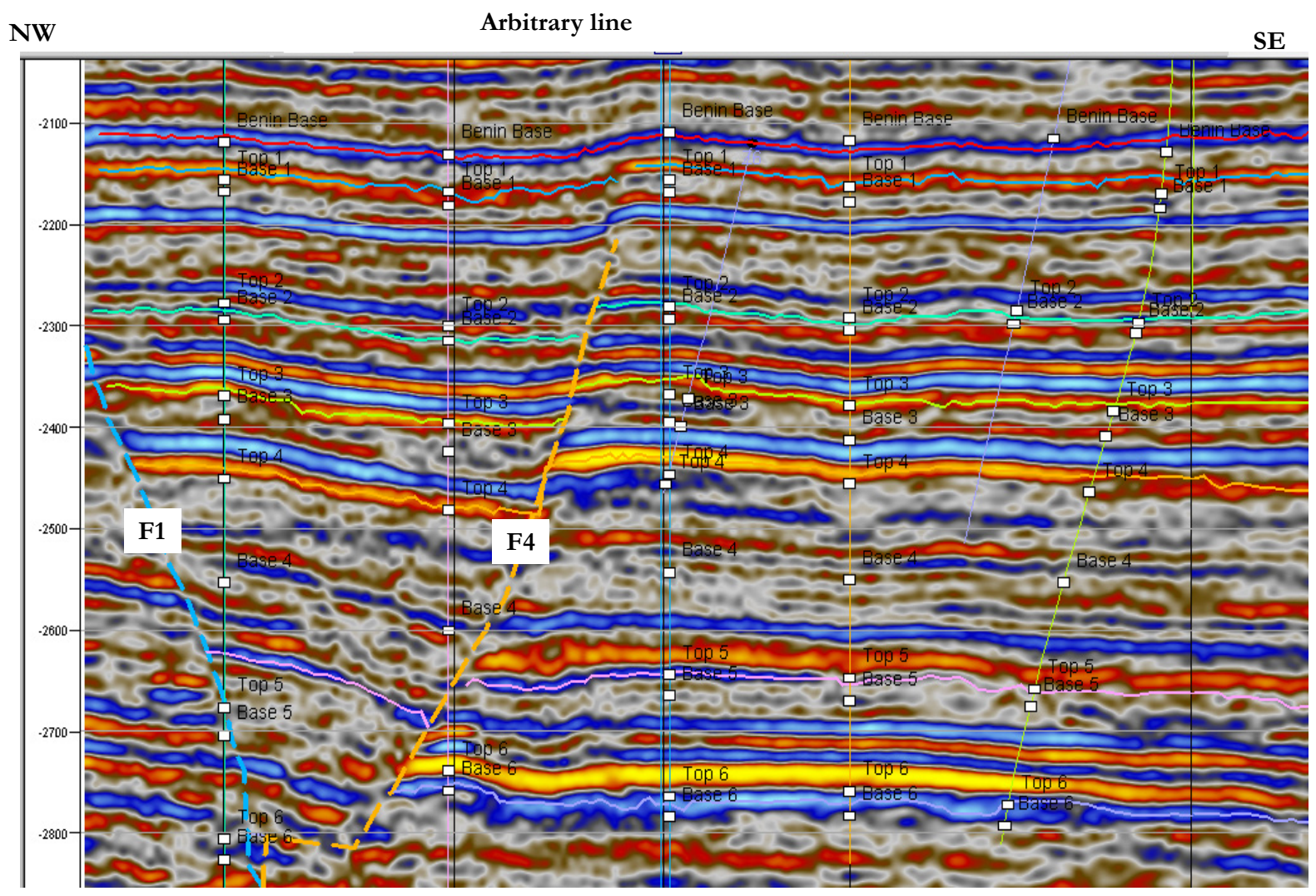

Figure $6 \mathrm{~b}$. An arbitrary section showing interpreted horizons with hydrocarbon trapping fault 4 


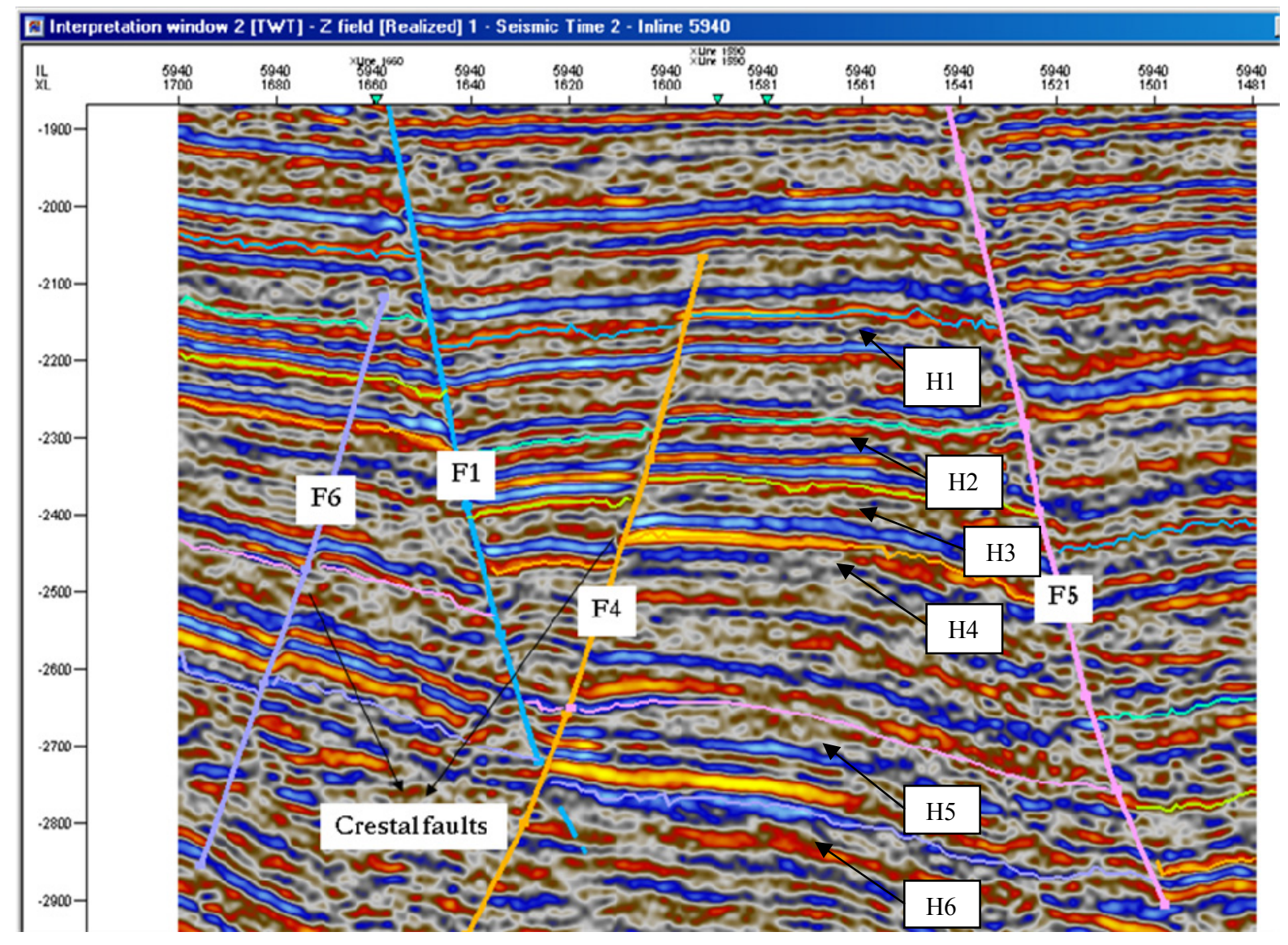

Figure 7. Manual horizon interpretation on inline 5940

\subsubsection{Fault Interpretation}

The structural framework was done by picking assigned fault segments on inline sections of seismic with the trace appearing on the corresponding cross lines. These faults are represented on the seismic sections as a discontinuous reflection along a preferred orientation of reflectors or as distortion of amplitude around the fault zones. A total of ten faults coded as F1, F2, F3, F4, F5, F6, F8, F9, F10 and F11 were identified (Figure 8a, 8b and $8 \mathrm{c}$ ), some extending through the extent of the field known as major regional growth faults, few flank faults appearing on few of the lines and listric crestal faults appearing within the seismic extent (Table 4). Two major regional growth faults F1 and F5 (Figure 7) were identified and correlated across the field forming the boundaries to the north and south of the field. The two major regional growth faults F1 and F5 and some other faults are dipping to the south away from direction of sediment supply, thus they are both regional faults while some of the other faults are dipping north, northwest, northeast, etc (Table 4). 


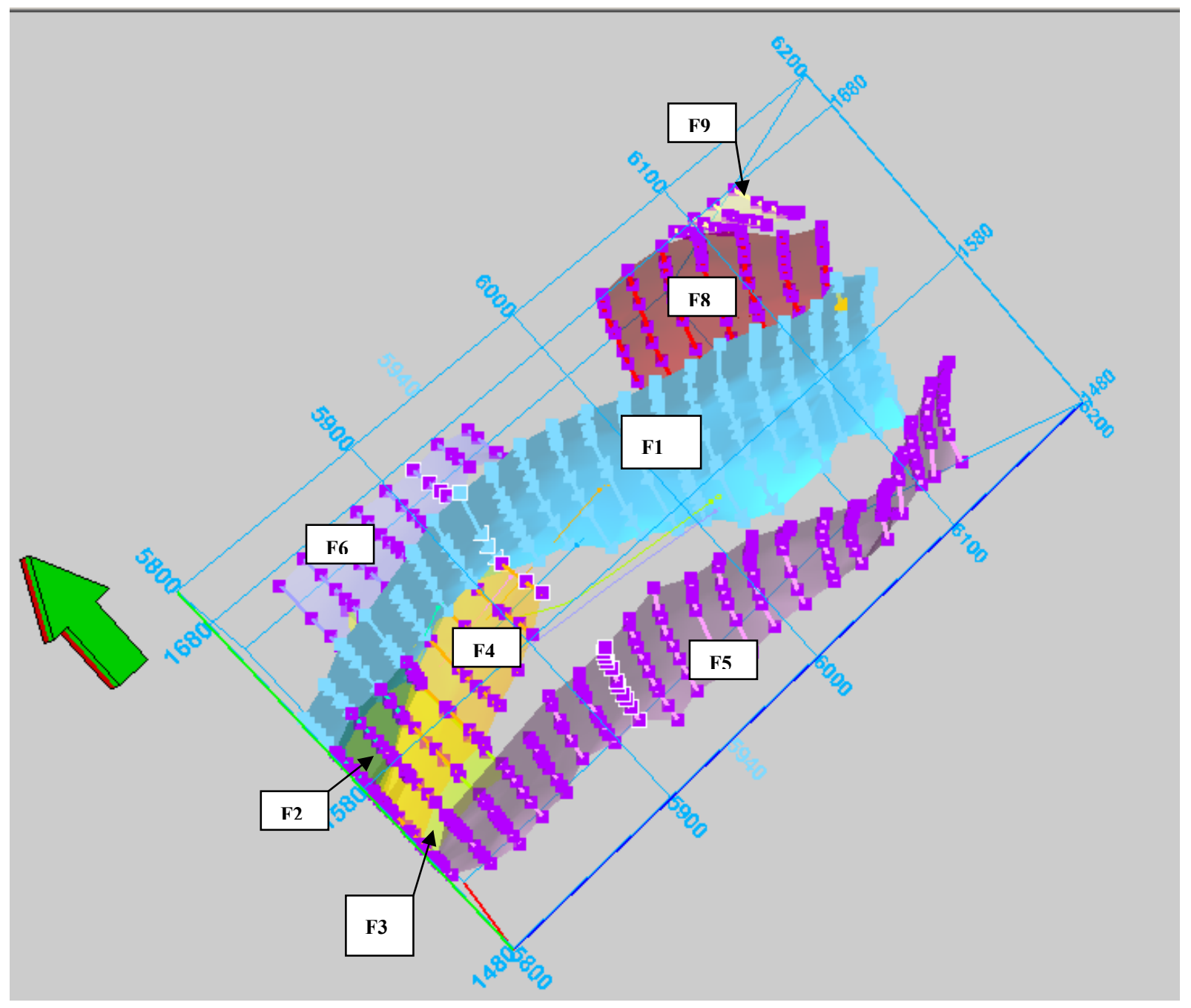

Figure 8a. Base map showing the identified faults (Viewed in NW-SE direction) 


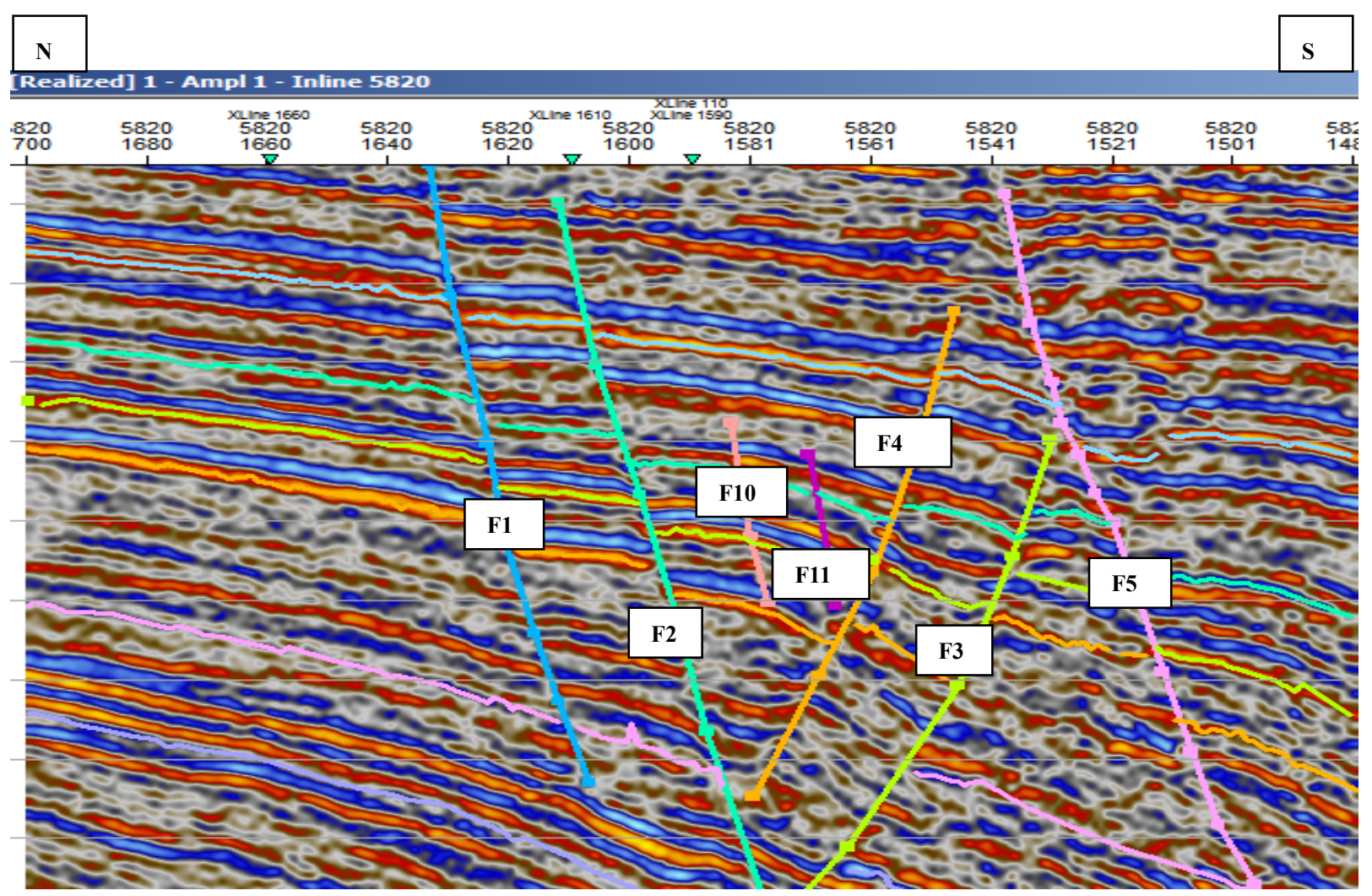

Figure 8b. Seismic section (inline 5820) showing the identified faults

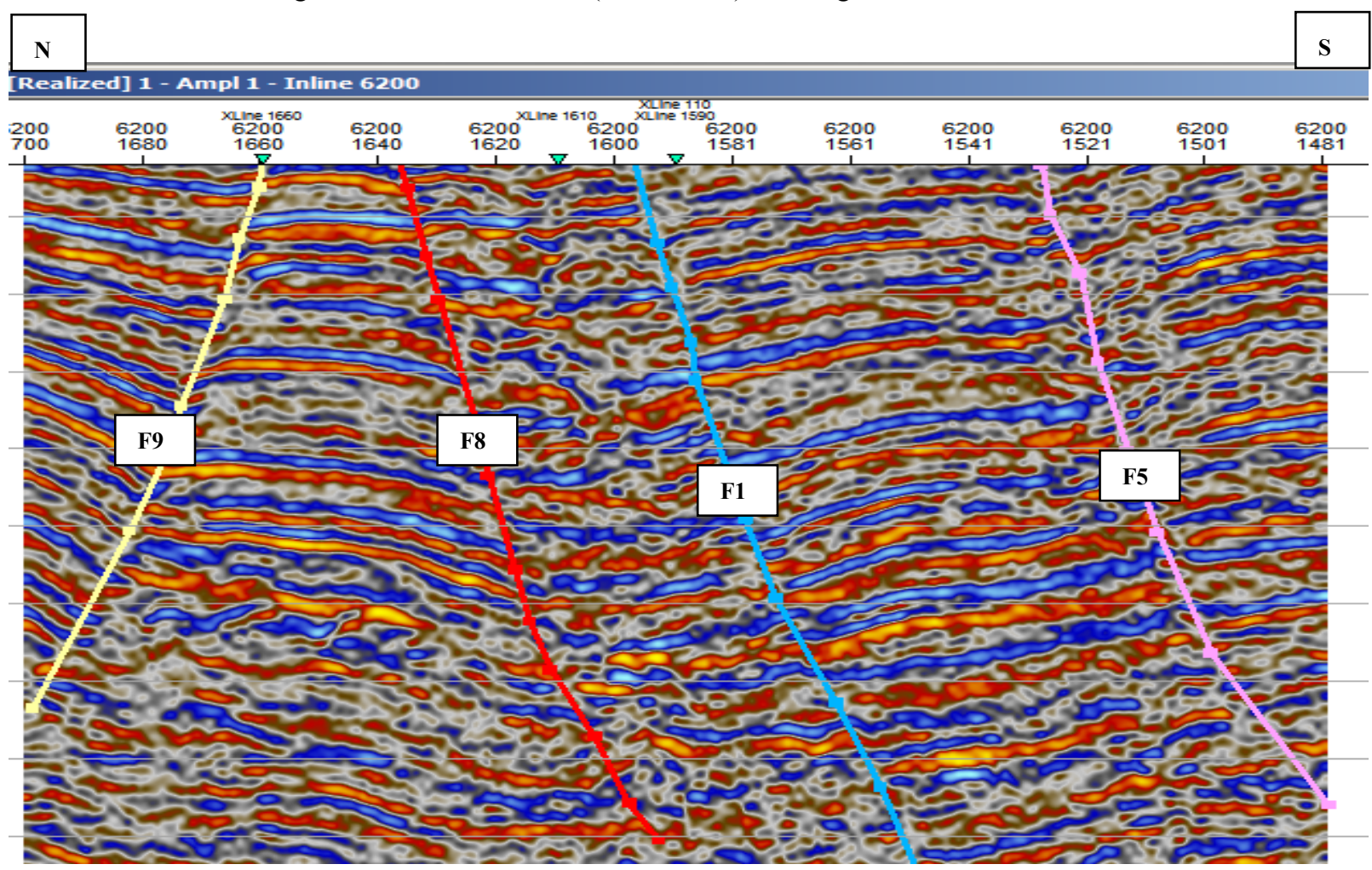

Figure 8c. Seismic section (inline 6200) showing the identified fault 
North dipping crestal fault F4 is an important trapping fault responsible for holding the hydrocarbon in Wells Z1, Z3, Z4 and Z6 named closure A. The upthrown block to the north of the field forms a prospect named closure B, trapped by the northern most regional growth fault F1 towards north eastern part of the field. The closure C prospect is a four-way closure to the spill point at shallow depth but becomes fault assisted on fault F1 and possibly fault F5 at deeper levels.

The hydrocarbon traps are basically fault assisted. Two prospects named closures B and C were identified based on closures formed in the northeastern part of the field and within the two regional growth faults F1 and F5.

Table 4. Showing interpreted faults with corresponding seismic coverage

\begin{tabular}{llll}
\hline FAULTS & DIP DIRECTION & INLINE COVERED & FAULT TYPE \\
\hline F1 & SOUTH & $5800-6200$ & MAJOR REGIONAL GROWTH \\
F2 & SOUTH & $5800-5880$ & FAULT \\
F3 & NORTH & $5800-5860$ & CRESTAL FAULT \\
F4 & NORTHWEST & $5800-5950$ & FLANK FAULT \\
F5 & SOUTH & $5800-6200$ & CRESTAL FAULT \\
F6 & NORTH & $5835-5990$ & MAJOR REGIONAL GRWOTH \\
F8 & SOUTH & $6080-6200$ & FAULT \\
F9 & NORTH & $6140-6200$ & COUNTER REGIONAL FAULT \\
F10 & SOUTH & $5800-5820$ & BACK TO BACK FAULT WITH F9 \\
F11 & SOUTH & $5800-5820$ & FLANK FAULT \\
\hline
\end{tabular}

\subsubsection{Horizon Interpretation}

A total of six horizons were interpreted across the field (Figure 7) with both time and depth maps generated for each of the horizon. Figures $9 \mathrm{a}$ and $9 \mathrm{~b}$ below shows the top surface maps of horizon 1 both in time and depth.

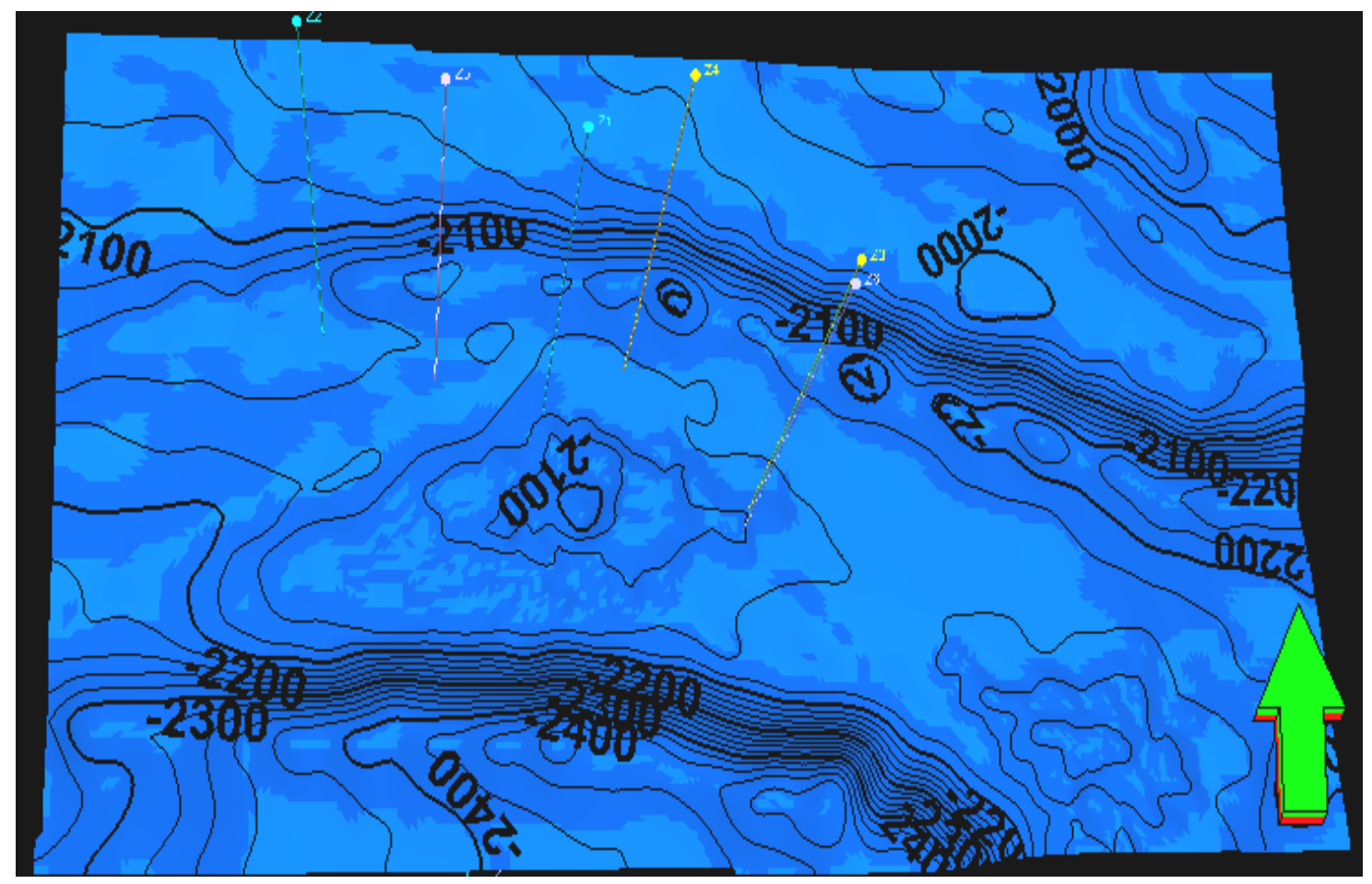

Figure 9a. Time map of horizon 1 showing identified closures 


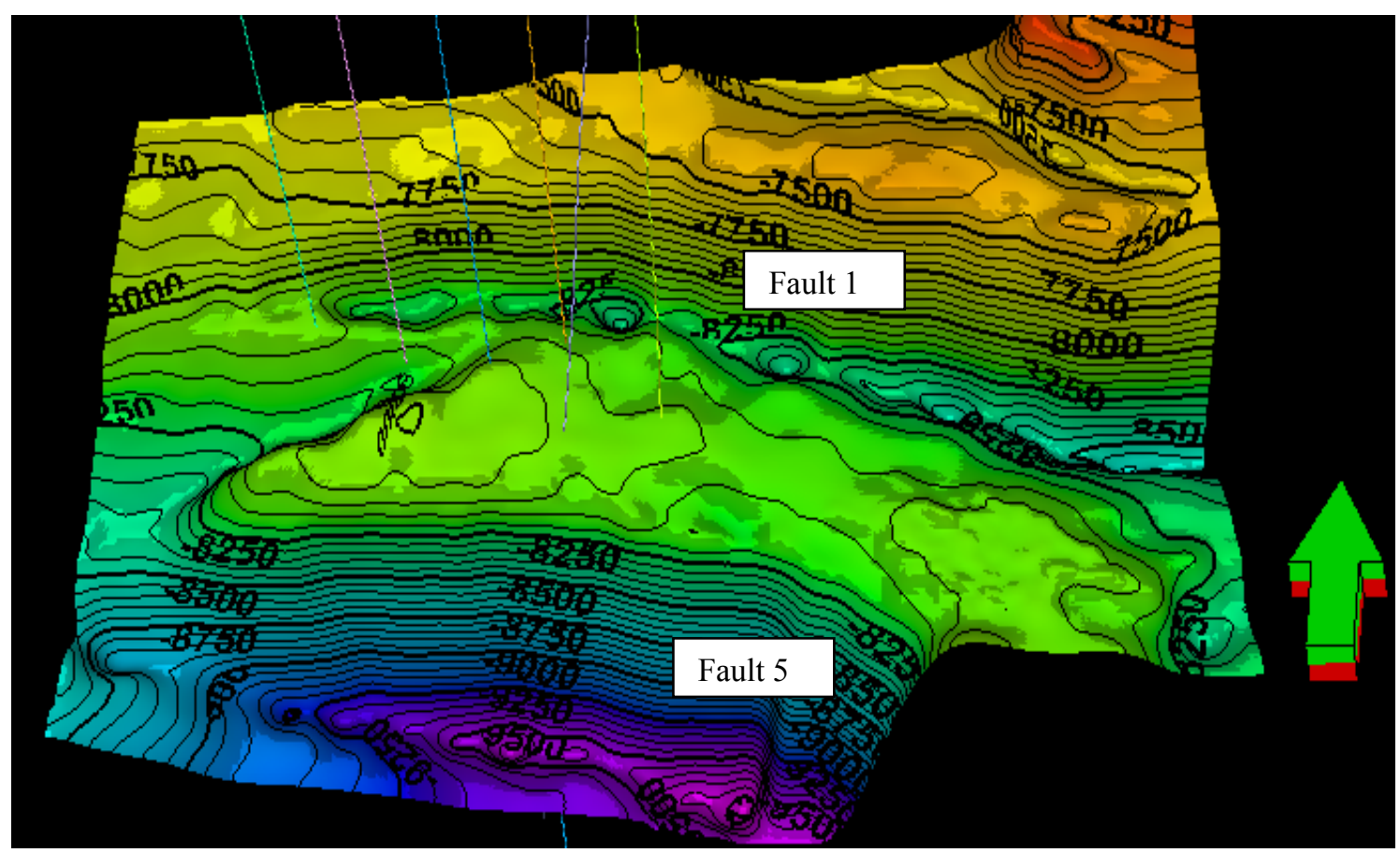

Figure 9b. Depth map of horizon 1 showing identified closures

\subsection{Attribute Analysis}

Five attributes (i.e. dip, azimuth, amplitude, envelope, frequency, and variance) were extracted and displayed as flattened maps (slice at 2155, 2277, 2368, 2446, 2644 and 2764ms) for each of the interpreted horizons. Structures respond to acoustic wave in different ways thus, the five attributes extracted are best used to study different subtle and sub-seismic structures missed by conventional seismic interpretation. Structural features such as closures and faults were studied in the course of this investigation. Tables 5 and 6 below show the summary of the attributes and corresponding structural features they enhance.

Table 5. Attributes and corresponding response to structural closures

\begin{tabular}{ll}
\hline Attributes & Time slice(s)(ms) associated with the attribute \\
\hline Amplitude & $2155,2277 \mathrm{~ms}$ \\
Azimuth & $2155,2277,2368,2446 \mathrm{~ms}$ \\
Dip & $2277 \mathrm{~ms}$ \\
Variance & $2155,2277,2368,2446,2644,2764 \mathrm{~ms}$ \\
Envelope & $2155,2277,2446 \mathrm{~ms}$ \\
\hline
\end{tabular}

Table 6. Attributes and corresponding response to structural closures

\begin{tabular}{ll}
\hline Attributes & Time slice(s)(ms) associated with the attribute \\
\hline Amplitude & $2155,2368,2446,2764 \mathrm{~ms}$ \\
Azimuth & No distinct pattern shown in all the slice \\
Dip & $2155,2277,2368,2446,2644,2764 \mathrm{~ms}$ \\
Variance & $2277,2368,2446 \mathrm{~ms}$ \\
Envelope & $2277,2368,2446,2764 \mathrm{~ms}$ \\
\hline
\end{tabular}


Figures 10 and 11 below shows that amplitude as an attribute can be used to identify prospect on a green field where no prior exploration work has taken place and also in areas where further exploration work is required.

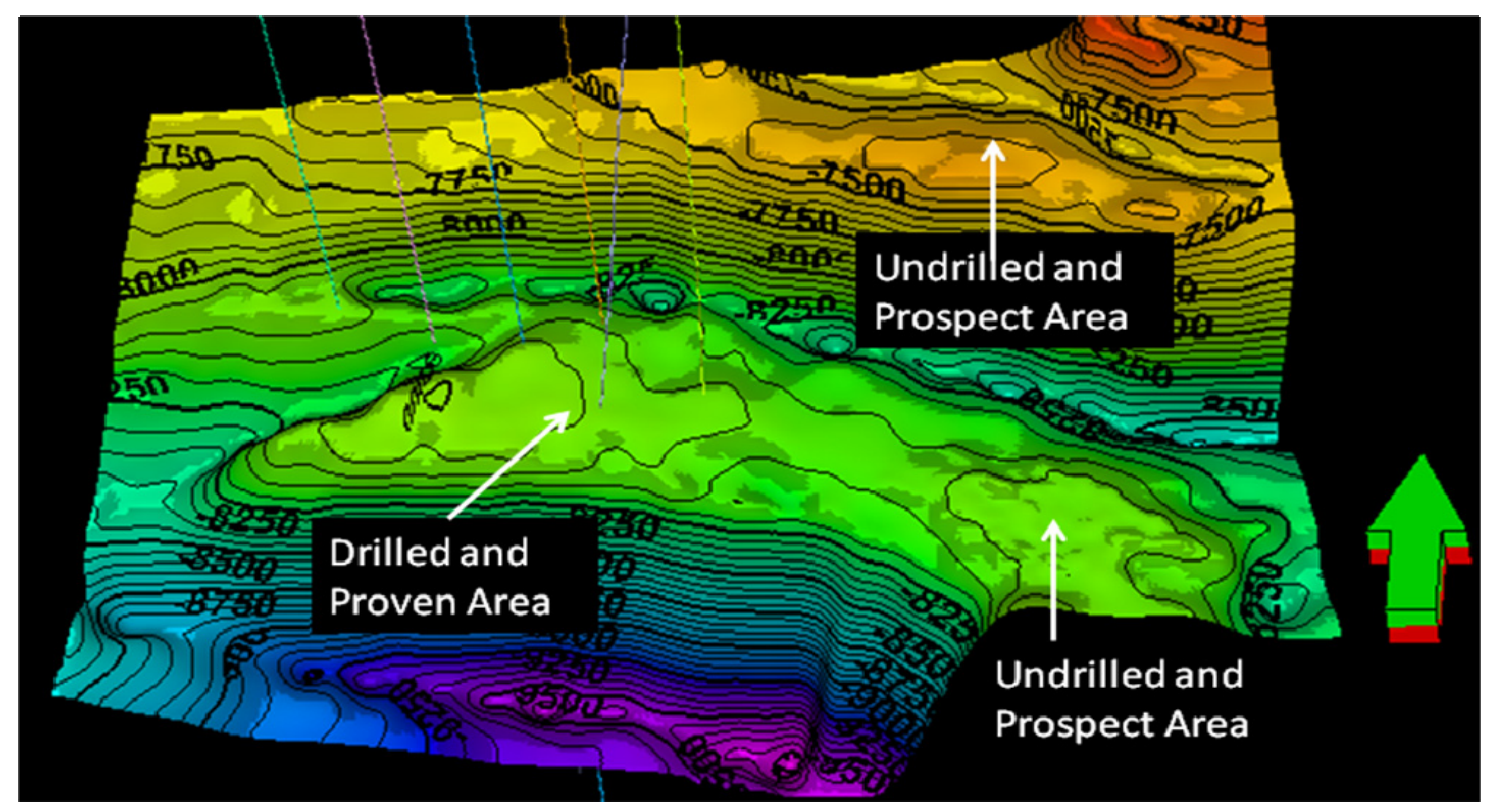

Figure 10. Depth map showing drillable prospects based on structural geometry

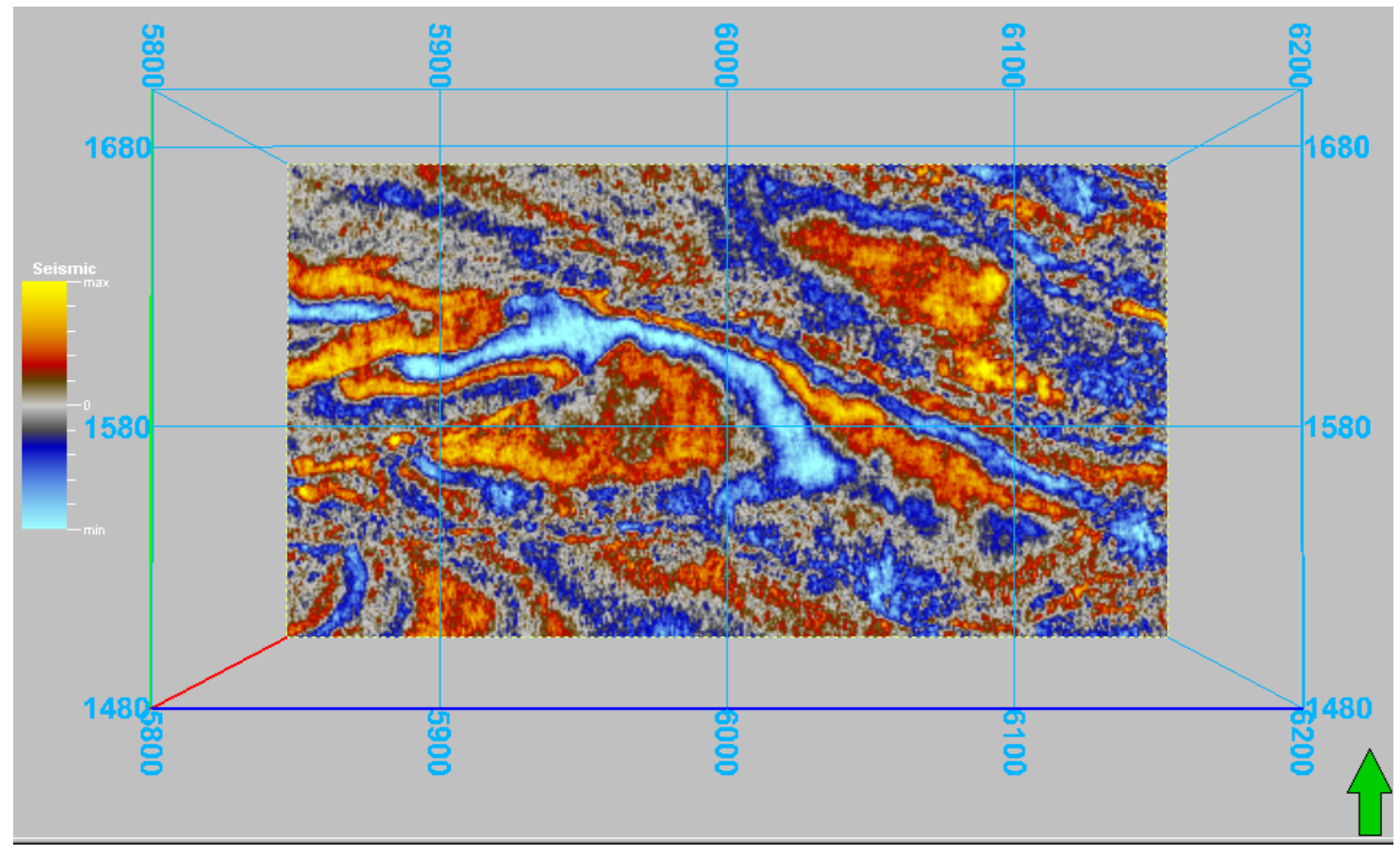

Figure 11. Amplitude map showing drillable prospects based on attribute extraction

During the course of the research, it was observed that, using conventional seismic interpretation method, fault 5 diminished to the southeast of the field. This fault was interpreted to have terminated as shown in Figure 12 but upon extracted variance attribute, it was clearly visible that F5 did not terminate as previously interpreted. 


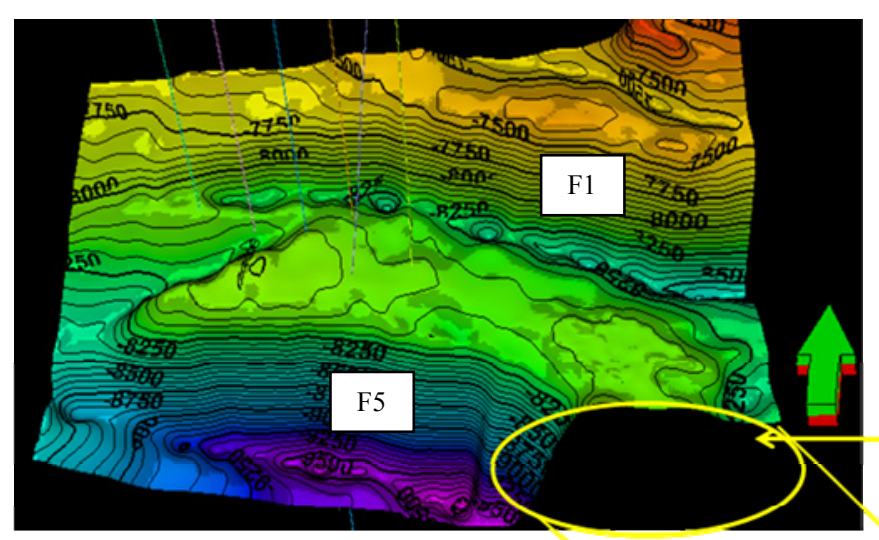

\section{The true fuult extent is shown nsing seismic attribute (variance) antalysis}

Figure 12. Variance and top structure map showing true fault extent of F5

Seismic attributes such as amplitude, envelope, dip, azimuth and variance were extracted based on horizon interpretation. The extracted attributes were analyzed and it was observed that variance showed better response to faults than any other attribute used for the study.

\section{Conclusion}

Interpretation of the 3D seismic data for locating both seismic scale and sub-seismic scale structural and stratigraphic elements has been demonstrated to be more efficient by the use of seismic attribute mapping and analysis. Variance attribute map has proved to be an appropriate tool to study fault architecture than dip attribute or any other attribute map in the study area. Therefore, to reduce the risk of drilling dry hole, resulting from missed fault by conventional seismic interpretation, seismic attribute analysis can be integrated into the standard practice of hydrocarbon Exploration and Production Company.

\section{Acknowledgement}

Thanks are due to the Department of Geosciences, University of Lagos for the opportunity to use their workstation facilities, Schlumberger Nigeria for Petrel software and DPR for providing the data.

\section{References}

Avseth, P., Mukerji, T., \& Mavko, G. (2005). Quantitative seismic interpretation (pp. 168-170). Cambridge University Press. http://dx.doi.org/10.1017/CBO9780511600074.005

Bracewell, R. N. (1965). The Fourier Transform and Its Applications (pp. 268-271). New York: McGraw-Hill.

Brown, A. R. (2004). Interpretation of three-dimensional seismic data (pp. 247-294, 6th ed.). American Association of Petroleum Geologists Memoir 42.

Chapin, M., Swinburn, P., \& van der Weiden, R. (2002). Integrated seismic and subsurface characterization of Bonga Field, offshore Nigeria. The Leading Edge, 11, 1125-1131. http://dx.doi.org/10.1190/1.1523745

Damuth, J. E. (1994). Neocene Gravity Tectonics and Depositional Processes on the Deep Niger Delta Continental Margin. Marine and Petroleum Geology, 11(3), 320-345. http://dx.doi.org/10.1016/0264-8172(94)90053-1 
Doust, H. (1989). The Niger delta: hydrocarbon potential of a major tertiary delta province: Proceedings, KNGMG Symposium "Coastal Lowlands, Geology and Geotechnology”, 1987: Dordrecht, Kluwer, 203-212.

Doust, H., \& Omatsola, E. (1990). Niger Delta. In J. D. Edwards, \& P. A. Santogrossi (Eds.), Divergent and Passive Margin Basins. American Association of Petroleum Geologists, Memoir, 48, 201-238.

Ekweozor, C. M., \& Daukoru, E. M. (1994). Niger Delta Depobelt Portion of the Akata-Agbada Petroleum System, AAPG Memoir 60: American Association of Petroleum Geologist, Tulsa, pp. 599-604.

Gauthier, D. M., \& Lake, L. W. (1993). Prediction of sub-seismic faults and fractures. pp. 35-48.

Klett, T. R., Ahlbrandt, T. S., Schmoker, J. W., \& Dolton, J. L. (1997). Ranking of worlds's Oil and Gas Provinces by known Petroleum volumes: U.S. Geological Survey Open-file report-97-463, pp. 56-58.

Kulke, H. (1995). Regional geology of the world, part 2: Africa, America, Australia and Antarctical: Berlin, Gebruder borntraeger, Kulke Ed.: 143-172.

Morgan, R. (2004). In at the Deep End: Geology and Exploration of the Niger Delta Ultra Deep-water Slope. PESGB London Evening Meeting.

Nissen, S. E. (2002). Seismic Attributes for the Explorationist. Kansas Geological Survey: Open-file Report No. 2002-49: North Midcontinent PTTC Petroleum Technology Fair.

Sheriff, R. E. (1992). Reservoir geophysics, Society of Exploration Geophysicist.

Sheriff, R. E., \& Geldart, L. P. (1995). Exploration Seismology (p. 592, 2nd Ed.). New York, USA: Cambridge University Press. http://dx.doi.org/10.1017/CBO9781139168359

Strecker, M. R., Carrapa, B., Hulley, G. E., Scoenbohm, L., \& Sobel, E. R. (2004). Erosional control of Plateau evolution in the Central Andes. Geological Society of America v. 36(5).

Taner, M., Koehler, F., \& Sheriff, R. (1979). Complex Seismic Trace Analysis. Geophysics, 44, 1041-1063. http://dx.doi.org/10.1190/1.1440994

Taner, M. T. (2001). Seismic attributes. Canadian Society of Exploration Geophysicists Recorder, 26(9), 48-56.

\section{Copyrights}

Copyright for this article is retained by the author(s), with first publication rights granted to the journal.

This is an open-access article distributed under the terms and conditions of the Creative Commons Attribution license (http://creativecommons.org/licenses/by/3.0/). 